\title{
PENGARUH PENERAPAN MODEL PEMBELAJARAN TIPE TEAM GAMES TOURNAMENT DI INTEGRASIKAN DENGAN STAD TERHADAP HASIL BELAJAR GEOGRAFI
}

\author{
Endang Endang ${ }^{a}$, Sunarty Eraku ${ }^{a}$, Fitriyane Lihawa ${ }^{a}$
}

a Jurusan Ilmu dan Teknologi Kebumian, Universitas Negeri Gorontalo, Jl. Jend. Sudirman No.8, Kota Gorontalo, Indonesia

\section{INFO ARTIKEL}

\section{Status artikel:}

Diterima: 08-08-2020

Disetujui: $31-08-2020$

Tersedia online: 04-09-2020

\section{Kata kunci:}

Cooperatif Learning, TGT, STAD,

Learning Outcomes

Penulis korespondensi:

Endang

Pendidikan Geografi, UNG

Email: Endang@gmail.com

DOI: $10.34312 /$ jgej.v1i2.7119

Copyright $\odot 2020$ JGEJ-UNG All Rights Reserved. \begin{abstract}
This study aims at determining the differences in student learning outcomes by involving two classes,i.e. the experimental classes taugtt by TGT learning model integrated with the STAD learning model as well as the control class taught by the STAD learning model. This experimental research involved all students of grade XI social sciences, namely the experimental class ( XI Social Sciences 2 ) and the control class ( XI Scocial Sciences 4 ). The hypothesis testing results show that the average learnig valuye of the students in the experimental class is 77,43 and the average learning value in the control class is 71,95 . Considering the hypothesis testing results in $\alpha=0,05$, it is found that $t_{\text {count }}=2,447>t_{\text {tabel }}=1.679$. This signifies that $\mathrm{H}_{0}$ is rejected ,and the scoes of student who lerning with the TGT cooperative learning model integration with the STAD learning model are higher that students who used the STAD cooperative learning model in Geograhy learning.
\end{abstract}

\begin{abstract}
ABSTRAK
Peneltian ini bertujuan untuk mengetahui perbedaan terhada hasil belajar siswa dengan melibatkan kelas eksperimen yang menggunakan model pembelajran TGT di integrasikan dengan model pembelajaran STAD dan kelas kontrol dengan menggunakaan model pembelajaran STAD. Penelitian ini merupakan penelitian eksperimen dengan populasi yaitu seluruh siswa kelas XI IPS SMA Negeri 3 Gorontalo dan diambil dua kelas sebagai sampel yaitu kelas eksperimen (XI IPS 2 ) dan kelas kontrol ( XI IPS 4 ).Dari pengujian hipotesis dapat di peroleh nilai rata-rata belajar ada siswa kelas eksperimen sebesar 77,43 dan rata-rata belajar pada kelas kontrol 71,95. Sedangkan pengujian hipotesis $\alpha=0,05$ didapatkan bahwa thitung $=2,447>t_{\text {tabel }}$ 1,679 Maka Ho di tolak dan di simpulkan nilai siswa yang dibelajarkan dengan model pembelajaran kooperatif TGT diintegrasikan dengan model pembelajaran STAD lebih tinggi dari pada siswa yang menggunakan model pembelajaran kooperatif tipe STAD pada pembeajaran Geografi.
\end{abstract} (CC-BY-NC) 4.0 International License

\section{Pendahuluan}

Hasil belajar masih menjadi tolak ukur keberhasilan pembelajaran. Kemampuan siswa dalam melakukan perubahan setelah melewati proses pembelajaran yang bisa di ukur dan diamati sehingga dapat disimpulkan bahwa siswa tersebut telah memenuhi Kriteria Ketuntasan minimal (KKM). Pada prosesnya, rendahnya hasil belajar siswa masih menjadi permasalahan yang serius untuk dibahas karena hasil belajar menjadi dasar dalam pencapaian tujuan pembelajaran yang dilaksanakan di kelas. Sedangkan pemahaman siswa untuk memahami materi pembelajaran sangat penting dalam mencapai tujuan pembelajaran.

Pembelajaran geografi memiliki karakter yang kompleks. Materi pembelajaran geografi membutuhkan kolaborasi antara siswa secara individu maupun dalam bentuk kelompok untuk memahami materi pembelajaran yang diberikan oleh guru (Rika, Purba Hajizah, Fatchan, A, Susilo, 2016). Pembelajaran geografi membutuhkan peran siswa untuk lebih aktif dan guru untuk kreatif. Salah satu jenis pembelajaran yang memenuhi karakter pembelajaran geografi dengan permasalahan tersebut adalah pembelajaran 
kooperatif (Safarina, 2018). Pembelajaran yang mengajarkan kepada siswa untu belajar secara bersama-sama dalam bentuk kelompok (Nurnawati et al., 2012)

Berdasarkan hasil pengamatan yang dilakukan di SMA Negeri 3 Gorontalo khususnya kelas XI IPS pada mata pembelajaran geografi masih ditemukan pembelajaran yang cenderung belum efektif diantaranya; (1) Minat siswa untuk mengikuti pembelajaran masih kurang. (2) Kurangnya kreativitas guru dalam menerapkan model pembelajaran yang bervariasi (3) Hasil belajar siswa SMA Negeri 3 Gorontalo khususnya kelas XI IPS masih banyak yang belum mencapai angka ketuntasan dan setiap kelas yang teramati hasil belajar siswa rata-rata nilai 60 sementara nilai kriteria ketuntasan mengajar adalah (KKM 75). (4) Pembelajaran yang ada belum secara maksimal melibatkan siswa yang aktif.

Perkembangan zaman telah berubah dan tentunya proses pembelajaran membutuhkan juga kreativitas dan mengikuti zaman. Salah satu pembelajaran kooperatif yang bisa membantu siswa untuk memahami materi pembelajaran adalah Teams Game Tournament (TGT). Dalam TGT, Siswa akan memainkan sebuah turnamen dalam bentuk permainan yang didesain secara aktraktif (Rahmawati et al., 2016). Sehingga pembelajaran, guru dan siswa membangun perasaan gembira (Utami, Dian 2018).

Pembelajaran dengan model TGT akan di integrasikan dengan STAD. STAD memiliki kelebihan dalam hal membangun kerjasama untuk menyelesaikan permasalahan tersebut. Pada model pembelajaran STAD, akan menggunakan kelompok kecil yang diperankan oleh para siswa, kemudian melakukan kerjasama dalam suasana belajar bersama untuk mencapai tujuan pembelajaran (Santoso \& Mudiono, 2017). Siswa akan memiliki banyak pengalaman secara langsung yang secara mental dan fisik yang berkembang dengan pembelajaran STAD (Susanti et al., 2017). Oleh sebab itu perlu di integrasikan dengan pembelajaran STAD yang lebih menekankan pada kolaborasi siswa. Pembelajaran yang dibangun adalah kelompok-kelompok dalam proses pembelajaran, siswa akan saling berbagi pikiran, membangun sifat saling memahami, bertanggung jawab sehingga secara sosial, kemampuan siswa dalam segi keterampilan sosialnya akan tumbuh dan berkembang (Suandi \& Lasmawan, 2013). Pembelajaran yang dilakukan dengan TGT yang menyenangkan dan STAD yang membangun kerjasama akan menghasilkan siswa yang mampu belajar secara individu dan berbagi dengan temannya.

\section{Metode}

Penelitian ini dilakukan di SMA Negeri 3 Gorontalo yang berlokasi di jalan Ki Hajar Dewantoro Kel.Limba U2 Kec.Kota Selatan Kota Gorontalo. Subyek dalam penelitian ini adalah seluruh siswa kelas XI IPS SMAN 3 Gorontalo yang terdiri 4 kelas :

Tabel 1. Sebaran Siswa Kelas XI IPS Di SMA N 3 Gorontalo

\begin{tabular}{cll}
\hline No & Kelas & Jumlah \\
\hline 1. & XI IPS 1 & 27 \\
\hline 2. & XI IPS 2 & 23 \\
\hline 3. & XI IPS 3 & 22 \\
\hline 4. & XI IPS 4 & 21 \\
\hline
\end{tabular}

Pengambilan sampel dalam penelitian ini dilakukan secara cluster random sampling (penarikan sampel pada kelompok secara random). Adapun langkah-langkah pengambilan sampel yaitu pertama dipilih dua kelas dari total empat kelas XI IPS yang ada di SMA 3 Gorontalo secara random, pemilihan kelas ini dilakukan untuk mendapatkan kelas eksperimen dan kelas control dan hasil yang didapat yaitu kelas XI IPS 2 dan kelas XI IPS 4 dan untuk menentukan kelas eksperimen adalah kelas XI IPS 2 dengan jumlah 23 orang siswa yang diberi perlakuan menggunakan model pembelajaran Teams Game Toutnament (TGT ) diintegrasikan dengan model pembelajaran Student Taems Achivement Divission ( STAD) dan kelas control adalah kelas XI IPS 4 dengan jumlah 21 orang siswa yang diberi perlakuan menggunanakan model pembelajaran kooperatif tipe Student Taems Achivement Divission ( STAD ) .

Penelitian ini merupakan penelitian eksperimen. Desain penelitian yang digunakan adalah post test only control design. Dalam desian ini diberikan perlakuan dengan menggunakan model pembelajaran teams game tournament ( TGT) diintegrasikan dengan model pembelajaran STAD. Kemudian menbandingkan hasilnya dengan kelas control yang diberi perlakuan dengan menggunakan model pembelajaran STAD. Dengan demikian hasil perlakuan dapat diketahui lebih akurat, karena membandingkan dengan keadaan sebelum diberi perlakuan. Desain ini dapat di gambarkan pada tabel 2 desain penelitian. 
Tabel 2 Desain Penelitian

\begin{tabular}{clll}
\hline No & Kelas & Perlakuan & Posttest \\
\hline 1. & Eksperimen & $\mathrm{X}_{1}$ & $\mathrm{Y}_{1}$ \\
\hline 2. & kontrol & $\mathrm{X}_{2}$ & $\mathrm{Y}_{2}$ \\
\hline
\end{tabular}

Keterangan :

$\mathrm{X}_{1=}$ pembelajaran dengan model pembelajaran kooperatif tipe TGT diintegrasikan dengan model pemblajaran STAD .

$\mathrm{X}_{2}=$ Pembelajaran dengan model pembelajaran koopertaif tipe STAD

$\mathrm{Y}_{1=}$ Tes akhir kelas eksperimen

$\mathrm{Y}_{2}=$ Tes akhir kelas kontrol

Instrumen yang digunakan dalam penelitian ini adalah tes hasil belajar. Tes yang digunakan yaitu dalam bentuk pilihan ganda. Tes digunakan untuk mengukur hasil belajar siswa terhadap materi yang diajarkan. Pemberian post-test untuk melihat hasil belajar dibuat berdasarkan indikator soal yang diambil dari tujuan pembelajaran. Adapun pada pengambilan analisis data ini dilakukan dengan beberapa pengujian antaranya adalah Pengujian normalitas data untuk mengetahui apakah data penelitian yang diperoleh berdistribusi normal atau tidak.Statistik uji yang digunakan adalah menggunakan rumus Chi kuadrat $\left(x^{2}\right)$.

Pengujian homoginitas dilakukan,untuk menentukan rumus yang akan dipilih pada pengujian hipotesis,maka perlu diuji duluh variasi kedua sampel homogeny atau tidak. Pengujian homoginitas pada penelitian ini dilakukan dengan menggunakan uji F (Fisher ). Uji F dapat dilakukan apabila data yang akan diuji hanya ada 2 kelompok data/sampel. Uji $\mathrm{F}$ dilakukan dengan cara membandingkan varial data terbesar dibagi variasi data terkecil.

Pengujian hipotesis bertujuan untuk mengetahui adanya perbedaan dalam hal belajar pada kelas eksperimen dan kelas control.Setelah pengujian normalitas data homoginitas data dilakukan ,maka hasil pengujian data tersebut digunakan dalam menentukan statistika uji yang akan digunakan pada pengujian hipotesis penelitian. Pengujiaan ini dimaksud untuk menentukan penyesuaian hasil belajar siswa pada kedua kelas objek penelitian apabila kedua data sampel penelitian distribusi normal.

\section{Hasil dan Pembahasan}

Penelitian ini dilakukan untuk mengetahui Pengaruh Penerapan Model Pembelajaran Kooperatif Tipe TGT diintegrasikan dengan model pembelajaran STAD terhadap Hasil Belajar Siswa pada Materi mitigasi bencana. Penelitian ini dilaksanakan di SMA Negeri 3 Gorontalo pada bulan Maret-April 2019. Jumlah sampel dalam penelitian ini adalah 44 siswa yang berasal dari dua kelas yang berbeda yaitu kelas kontrol dan kelas eksperimen. Untuk kelas kontrol berjumlah 23 siswa dan kelas eksperimen berjumlah 21 siswa. Dalam pengambilan subjek ini peneliti mengunakan teknik Clanster Random Sampling (sampling acak berkelompok) dengan pertimbangan siswa memdapatkan materi berdasarkan kurikulum yang sama dan siswa diajarkan oleh guru yang sama.

Berdasarkan hasil tes belajar yang diberikan kepada siswa diakhir pembelajaran, diperoleh dua kelompok nilai yaitu kelompok nilai eksperimen dan kelompok nilai kontrol. Kelompok nilai eksperimen adalah skor hasil belajar siswa menggunakan model pembelajaran TGT diintegrasikan dengan model pembelajaran STAD. Tabel 3 disajikan data hasil belajar siswa yang terkumpul sesudah pembelajaran post test skor masing-masing data ini dideskripsikan dalam bentuk nilai hasil belajar.

Tabel 3. Nilai Rata-rata hasil belajar siswa

\begin{tabular}{|c|c|c|c|c|c|}
\hline \multirow[t]{2}{*}{$\begin{array}{l}\text { Jumlah } \\
\text { Responden }\end{array}$} & $\begin{array}{l}\text { Ke } \\
\text { Ek }\end{array}$ & nen & $\begin{array}{l}\text { Jumlah } \\
\text { Responden }\end{array}$ & \multicolumn{2}{|c|}{ Kelas kontrol } \\
\hline & \multicolumn{2}{|c|}{ Nilai } & & & Nilai \\
\hline \multirow[t]{2}{*}{23} & Jumlah & 1781 & \multirow[t]{2}{*}{21} & Jumlah & 1511 \\
\hline & Rata-rat & 77,43 & & Rata-ratc & 71,95 \\
\hline
\end{tabular}


Hasil tes belajar yang diperoleh dari data tabel 3 mengungkapkan bahwa nilai rata-rata kelas ekperimen lebih tinggi dibandingkan dengan nilai rata-rata kelas kontorol. Hal tersebut membuktikan bahwa pembelajaran dengan model TGT yang di integrasikan dengan STAD berpengaruh terhadap signifikan terhadap hasil belajar.

Jumlah soal yang digunakan sebagai tes hasil belajar adalah 25 butir soal dengan bentuk pilihan ganda. Adapun jumlah siswa terdiri dari dua kelas XI IPS 1 yang dijadikan sebagai kelas eksperimen dengan kelas kontrol yaitu kelas XI IPS 2 dan untuk kelas eksperimen terdiri 23 siswa kelas dan kelas kontrol terdiri dari 21 siswa.Berikut merupakan perbedaan hasil belajar siswa kelas eksperimen dan kelas kontrol yang dapat dilihat pada gambar dibawah ini.

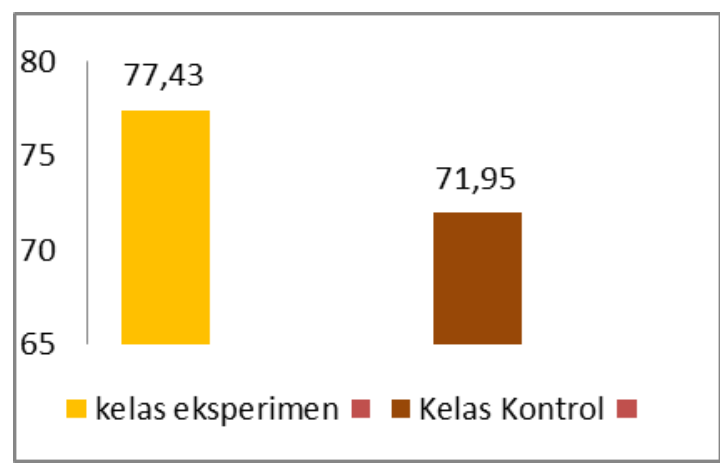

\section{Grafik 1. Hasil Belajar Siswa Kelas Eksperimen dan Kelas Kontrol}

Berdasarkan grafik 1 dapat diketahui bahwa rata-rata untuk kelas eksperimen sebesar 77,43 nilai tersebut diperoleh dari hasil pelaksanaan tes hasil belajar siswa untuk kelas eksperimen yang diberikan perlakuan dengan menggunakan model pembelajaran TGT di integrasikan dengan model pembelajaran STAD, sedangkan dapat diketahui rata -rata skor untuk kelas kontrol sebesar 71,95. Siswa yang diberikan perlakukan menggunakan pembelajaran kooperatif lebih cepat dalam proses recalling dibandingkan dengan siswa yang tidak diberikan perlakukan pembelajaran kooperatif. Perbedaan nilai rata-rata dari kelas kontrol dan eksperimen mengungkapkan bahwa pembelajarn TGT yang di integrasikan dengan STAD menjadikan siswa lebih semangat, senang dan memiliki rasa kebersamaan.

Pada hasil perhitungan uji normalitas yang dilakukan dikelasa eksperimen dan kelas kontrol diperoleh hasil sebagai berikut:

Tabel 4. Uji Normalitas Post Test Kelas Eksperimen dan Kelas Kontrol

\begin{tabular}{cccccc}
\hline Kelas & $\mathrm{N}$ & Kriteria & $\mathrm{L}_{\text {hitung }}$ & $\mathrm{L}_{\text {tabel }}$ & Kesimpulan \\
\hline Eksperimen & 23 & Posttest & 0,13 & 0,17 & Berdistribusi \\
\hline Kontol & 21 & & 0,16 & 0,18 & Normal \\
\hline
\end{tabular}

Pada tabel 4. menunjukan hasil posttest dengan jumlah $\mathrm{N}$ ( jumlah responden) 23 siswa dengan taraf signifikan $\alpha=0,05$ maka $\mathrm{L}_{\text {tabel }} 0,17$. Hal ini menunjukan untuk posttest $\mathrm{L}_{\text {hitung }}<\mathrm{L}_{\text {tabel }}$ sehinggga Ha diterima maka sampel berdistribusi normal. ini.

Lalu pada hasil perhitungan uji homogenitas menggunakan uji fisher dapat dilihat pada tabel dibawah

Tabel 5. Hasil Uji Homogenitas

\begin{tabular}{l|l|c|c|c}
\hline \multicolumn{2}{c|}{ Varians sampel } & \multirow{2}{*}{ Fhitung $_{n}$} & $\mathrm{~F}_{\text {tabel }}$ & Kesimpulan \\
\cline { 1 - 2 } Eksperimen & Kontrol & & & \\
\hline 59,98 & 51,14 & 1,1 & 2,1 & Homogen \\
\hline
\end{tabular}

Berdasarkan data tabel 4.3 bahwa hasil pengujian homogenitas menggunakan posttest diperoleh data $\mathrm{F}_{\text {hitung }}<\mathrm{F}_{\text {tabel }}$ maka $1,1<2,1$. Pada taraf signifikan 0,05 dengan derajat kebebasan $(\mathrm{dk})$ penyebutan= 20 dan 
derajat kebebasan $(\mathrm{dk})$ pembilang $=22$ maka dengan demikian Ho diterima. Hal ini menunjukan bahwa sampel kedua kelompok memiliki varians yang homogen.

Setelah dilakukan uji normalitas data dan uji homogenitas varians, maka dilanjutkan dengan pengujian hipotesis yang di hitung dengan menggunakan uji statistika uji t. tujuan dari pengujian hipotesis ini yakni untuk mengetahui adanya pengaruh model pembelajaran TGT ( Teams Gemes Tournament) yang dilihat dari perbedaan hasil belajar siswa antara kelas eksperimen yang menggunakan model pembelajaran TGT ( Teams Gemes Tournament) di integrasikan dengan model pembelajaran STAD dan kelas kontrol yang menggunakan model pembelajaran STAD.

Berdasarkan hasil perhitungan atau analisis statistika ,maka diperoleh $t_{\text {hitung }} 2,447$ dan nilai pada $\alpha=0,05$ $\mathrm{dk}=\left(\mathrm{n}_{1+} \mathrm{n}_{2-2}=23+21-2=42\right)$. Dengan demikian $\mathrm{t}_{\text {hitung }}$ lebih besar dari $\mathrm{r}_{\mathrm{tabel}}\left(\mathrm{t}_{\text {hitung }}=2,44>\mathrm{t}_{\text {tabel }}=1,67\right)$. Apabila $\mathrm{t}$ hitung $\neq \mathrm{t}_{\text {tabel }}$ maka terdapat perbedaan hasil belajar siswa dengan kata lain $\mathrm{t}_{\text {hitung }}$ berada diluar penerimaan Ho ( Ho ditolak ) yang berarti menerima hipotesis $\left(\mathrm{H}_{1}\right.$ diterima $)$. Berdasarkan hasil penelitian disimpulkan terdapat pengaruh model pembelajaran TGT (Teams Gemes Tournament) diintegrasikan dengan model pembelajaran STAD terhadap hasil belajar siswa di SMA Negeri 3 Gorontalo. Maka dari itu sudah tentu nilai rata-rata hasil belajar siswa yang dibelajarkan model pembelajaran kooperatif tipe TGT diintegrasikan dengan model pembelajaran STAD dikategorikan sangat tinggi dibandingkan dengan model pembelajaran kooperatif tipe STAD.

\section{Kesimpulan}

Berdasarkan hasil pengujian hipotesis serta pembahasan dapat disimpulkan bahwa terdapat perbedaan antara hasil belajar siswa dengan menggunakan model pembelajaran kooperatif tipe TGT diintegrasikan dengan model pembelajaran STAD pada mata pembelajaran Geografi di SMA Negeri 3 Gorontalo. Hal ini nampak dari hasil uji hipotesis bahwa nilai thitung $=2,447>$ ttabel $=1,679$. Dengan demikian pula rata-rata hasi belajar siswa pada kelas eksperimen 77,43 jika dibandingkan dengan nilai rata-rata pada kelas kontrol adalah 71,95. Dimana hasil belajar siswa yang dibelajarkan dengan model pembelajaran TGT diintegrasikan dengan model pembelajaran STAD pada materi mitigasi bencana di SMA Negeri 3 Gorontalo lebih tinggi dibandingkan dengan menggunakan model pembelajaran STAD.

\section{Referensi}

Nurnawati, E., Yulianti, D., \& Susanto, H. (2012). Peningkatan Kerjasama Siswa Smp Melalui Penerapan Pembelajaran Kooperatif Pendekatan Think Pair Share. UPEJ (Unnes Physics Education Journal), 1(1). https://doi.org/10.15294/upej.v1i1.764

Rahmawati, A., Abdi, A. W., \& Bardi, S. (2016). Penerapan Model Pembelajaran Team Games Tournamentmenggunakan Media Permainan Interaktif Ludo Untuk Meningkatkan Hasil Belajar Siswa Sma Inshafuddin Banda Aceh. Jurnal Ilmiah Mahasiswa FKIP Unsyiah, 1(1), 49-54.

Rika, Purba Hajizah, Fatchan, A, Susilo, S. (2016). Pengaruh kombinasi model. PENGARUH KOMBINASI MODEL PROBLEM BASED LEARNING DENGAN TEAM GAMES TOURNAMENT TERHADAP HASIL DAN MINAT BELAJAR GEOGRAFI SISWA MAN REJOTANGAN KABUPATEN TULUNGAGUNG, 21(1), 44-52.

Safarina, E. I. (2018). Pengaruh Model Pembelajaran Kooperatif TGT. Natural:Jurnal Ilmiah Pendidikan IPA, 5(1), 32-38.

Santoso, A., \& Mudiono, A. (2017). Peningkatan Keterampilan Menulis Narasi Melalui Penerapan Model Stad Berbantu. Jurnal Pendidikan, 2(11), 1504-1508.

Suandi, M. S., \& Lasmawan, W. (2013). TIPE STAD TERHADAP HASIL BELAJAR IPS DAN KETERAMPILAN SOSIAL SISWA KELAS V SD NEGERI 1 JEROWARU LOMBOK TIMUR e-Journal Program Pascasarjana Universitas Pendidikan Ganesha. 3(3).

Susanti, Y., Wahjoedi, W., \& Utaya, S. (2017). Peningkatan Aktivitas dan Hasil Belajar Siswa Melalui Pembelajaran Kooperatif Tipe STAD. Jurnal Pendidikan: Teori, Penelitian, Dan Pengembanga, 2(5), 661-666.

Utami, D. (2018). PENGARUH MODEL PEMBELAJARAN TEAMS GAMES TOURNAMENT TERHADAP MINAT BELAJAR GEOGRAFI SISWA SMA Dian Utami. Jurnal Swarnabhumi, 3(2), $81-88$. 